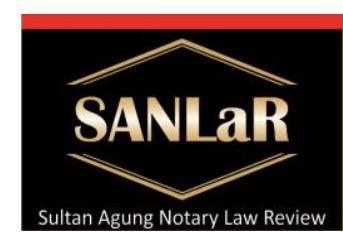

Volume 2 Issue 2, June 2020

\section{Sultan Aqung Notary Law Review}

Notary Authority in Installing Mortgage as Effort to...( Agung Nugroho)

ISSN 2686-4428

published by

Master of Notarial Law Faculty of Law Semarang

\title{
Notary Authority in Installing Mortgage as Effort to Settle Bad Credit (Second Way Out)
}

\author{
Agung Nugroho*) and Sukarmi ${ }^{* *}$ \\ *) Bank Jateng staff, E-Mail: agungnr017@gmail.com \\ $\left.{ }^{* *}\right)$ Lecturer of Master of Notary Law, Universitas Islam Sultan Agung (UNISSULA) \\ Semarang
}

\begin{abstract}
The role of a notary is very important in helping to create legal certainty and protection for the community, because a notary as a general official has the authority to make authentic deeds, as long as the making of the authentic deed is not specific to other public officials. The implementation of the Deed of Granting Mortgage Rights to Banks is inseparable from the role of the Notary and Land Deed Making Official (PPAT). Activities between the bank and the debtor who transfer the Guarantee Rights guarantee are very interested in making an agreement between them. The approach method used in this study is a sociological juridical approach and is included in descriptive-analytical legal research. The data source used is primary data. The data source used a purposive sample which focuses on selected informants who are rich in cases for in-depth studies. The results of this study are as follows: (1) Installation of Mortgage with APHT which is the authority of the PPAT position in accordance with the provisions of the UUHT is sufficient to be preceded by an underhand Credit Agreement; (2) The notary has a preventive role in credit settlement, ensuring that the rights and obligations of the parties are equally well fulfilled and legally protected and (3) The legal consequence of the installation of the Mortgage is that the Bank can carry out an auction for the execution of the Mortgage through a second way out. If the debtor is stuck. Banks do not need to ask the debtor for approval if they are going to conduct an auction.
\end{abstract}

Keywords: Authority; Mortgage; Bad Credit; Effort.

\section{Introduction}

Data from Bank Indonesia shows that one of the largest commercial business activities of banks is credit. By taking into account and considering the conditions of the banking business, credit business activities should be properly managed so that the level of risk can be controlled. ${ }^{1}$

Lending is a bank's main activity that carries risks that can affect the health and sustainability of the bank's business ${ }^{2}$. However, considering that as an intermediary institution, most bank funds originate from public funds, so credit extension is largely limited by the provisions of the laws and regulations of Bank Indonesia ${ }^{3}$. The Banking

\footnotetext{
1 Usanti, Prasastinah and Bakarbessy. (2014). Buku Referensi Hukum Perbankan: Hukum Jaminan, Surabaya: Revka Petra Media. p. 34-35

2 Rachmayani and Suwandono. (2017). "Covernote Notaris dalam Perjanjian Kredit dalam Perspektif Hukum Jaminan", Jurnal Hukum Kenotariatan dan ke-PPAT-an, ISSN: 2614-3542 EISSN: 2614-3550 Volume 1, Number 1, December 2017

3 Usman, Rachmadi. (2011). Aspek-Aspek Hukum Perbankan di Indonesia. Jakarta: Gramedia Pustaka Utama. p. 76
} 
Law has mandated banks to always adhere to the principle of prudence in carrying out their business activities, including providing credit. ${ }^{4}$

In connection with the complex bank business in the process of extending credit, creditors and debtors and other related parties should receive protection through a strong guarantee rights institution that can also provide legal certainty for all interested parties. ${ }^{5}$

The mortgage guarantee institution is used to bind the object of the debt guarantee in the form of land or objects related to the land in question ${ }^{6}$. According to Article 1 Paragraph (1) of Act No. 4 of 1996 concerning Mortgage Rights for Land and objects related to Land (UUHT), Mortgage Rights for land and objects related to land, hereinafter referred to as Mortgage Rights, are security rights imposed on land rights as referred to in Act No. 5 of 1960 concerning Basic Agrarian Principles, along with other objects which are an integral part of the land, for the settlement of certain debts, which provide a position that gives priority to certain creditors over other creditors. ${ }^{7}$

The role of a notary is very important in helping to create legal certainty and protection for the community, because a notary as a general official has the authority to make authentic deeds, as long as the making of the authentic deed is not specific to other public officials. Legal certainty and protection can be seen through the authentic deed which he makes as perfect evidence in court. The proof is perfect because authentic deeds have three evidentiary powers, namely the power of proof (Uitwendige Bewijsracht), the power of formal proof (Formele Bewijskrach) and the power of proof of material (Material Bewijskracht). ${ }^{8}$

The implementation of the Deed of Granting Mortgage Rights to Banks is inseparable from the role of Notaries and Land Deed Making Officials (PPAT). Activities between the bank and the debtor who transfer the Guarantee Rights guarantee are very interested in making an agreement between them. From the banking point of view, the notary deed is strong evidence and serves as protection for the bank in the credit agreement as the main agreement of the Guarantee Rights guarantee agreement.

For credit guarantees with Mortgage Rights, a PPAT deed is required which is an official who is authorized to make an authentic deed relating to land because Mortgage Rights are rights imposed on the following land or not along with the objects on it. Mortgage Rights are used as the ultimate for banks to resolve the risk of bad debts from their debtors.

\footnotetext{
${ }^{4}$ Setyaningsih and Mashdurohatun. (2018). "Peranan Notaris Dalam Pembuatan Akta Pemberian Hak Tanggungan (APHT) Terhadap Perjanjian Kredit Antara Kreditur Dan Debitur Dengan Jaminan Hak Tanggungan Di Purwokerto". Jurnal Akta Vol 5 No 1 March 2018: 187-196, http://jurnal.unissula.ac.id/index.php/akta/article/view/2547

5 Adrian Sutedi. (2006). Implikasi Hak Tanggungan Terhadap Pemberian Kredit Oleh Bank dan Penyelesaian Kredit Bermasalah. Jakarta: BP Cipta Jaya. p. 1

${ }^{6}$ Firdaus, Rahmat. (2011). Manajemen Perkreditan Bank Umum, Fifth Printing. Bandung: Alfabeta. p. 46

${ }^{7}$ Adrian Sutedi, Op. Cit., p. 3

${ }^{8}$ G. H. S. Lumban Tobing. (1999). Peraturan Jabatan Notaris, Gelora Aksara Pratama. Jakarta: p. 55-59
} 
Based on the description above, this study aims to analyze Notary's authority in installing Mortgage Rights is reviewed based on Law No. 2 of 2014 concerning the Position of Notary Public; efforts made by a Notary in the context of settling bad debts; as well as the legal consequences of Mortgage when there is bad credit.

\section{Research Methods}

The approach method in this research is sociological juridical, while the specification of this research is descriptive analysis. The data source in this study is primary data, namely based on interviews, with a purposive sample method (purposive sample).

\section{Results and Discussion}

\subsection{Notary's Authority in Installing Mortgage Rights}

The authority of a Notary listed in the Law concerning the Position of Notary Public and which can be exercised is only eleven powers, one of which is the authority to make an authentic deed. An authentic deed is a deed made by or before a notary. An authentic deed made by a notary, includes: ${ }^{9}$

a. All deeds,

b. Agreement,

c. Determination required by laws and regulations, and/or

d. What the interested parties want to be stated in the authentic deed.

The legal product made by a notary in accordance with his/her authority in the legal relationship between the debtor and creditor is the Credit Agreement Deed. The next stage is the installation of Mortgage Rights. The stage of granting Mortgage Rights is preceded by a promise to provide Mortgage Rights. According to Article 10 Paragraph (1) of the Mortgage Rights Law, this promise must be stated and is an inseparable part of the debt and credit agreement. ${ }^{10}$

The process of imposition of Mortgage Rights is carried out in two stages of activity, namely: ${ }^{11}$

a. The stage of Granting Mortgage Rights which is carried out before the Official for Making Land Deeds (PPAT), which is preceded by a guaranteed debt and credit agreement.

b. Registration stage is carried out at the local Regency or Municipal Land Office.

According to Article 13 of the Mortgage Rights Law, the granting of security rights must be registered at the Land Office no later than 7 (seven) working days after the signing of the APHT, PPAT is obliged to send the relevant APHT and other required documents. The documents in question include letters of evidence relating to the object of mortgage rights and the identity of the parties concerned, including certificates of land

\footnotetext{
${ }^{9}$ Interview with Mrs. Made Linggarasih, SH (PPAT notary for the working area of Grobogan Regency (a partner of Bank Jateng, Purwodadi Branch) On March 9, 2020

${ }^{10}$ Asyhadie, Zaeni and Rahma Kusumawati. (2018). Hukum Jaminan di Indonesia. Depok: Raja Grafindo. p. 223

${ }^{11}$ Adjie, Habib. (2018). Hak Tanggungan Sebagai Lembaga Jaminan atas Tanah. Bandung: Mandar Maju. p. 10
} 
rights and/or certificates regarding objects of security rights. PPAT is obliged to do this because its position and witnesses to such violations will be stipulated in the statutory regulations governing the PPAT position.

\subsection{Efforts made by Notaries in Settling Bad Credit}

Notaries do not have a direct role in the credit running process. The main role of the Notary is at the beginning of the provision of credit, in relation to the Credit Agreement process to the installation of Mortgage Rights against the credit guarantee owned by bank debtors ${ }^{12}$.

Notaries play an indirect role, namely preventive efforts. Ensure that the deed made must be clean and clear against errors that may create loopholes for future lawsuits. Both in terms of subject and legal object. The notary must be able to protect all legal aspects as well as the interests of both the debtor, creditor and the notary personally. ${ }^{13}$

\subsection{Legal consequences of Mortgage When Bad Credit Occurs}

Not always the credit given by the Bank to the debtor will run smoothly as expected in the credit agreement. External and internal environmental conditions (from the customer side and from the Bank's side), can affect the smoothness of the Debtor's obligations to the Bank so that loans that have been distributed to Debtors have the potential to become bad or default.

External environmental conditions that can affect failure to extend credit include the following:

a. Changes in economic conditions and policies or regulations that affect the debtor's business sector or sector. These changes are a continuous challenge faced by company owners and managers. The key to success in a business is the ability to anticipate change and be flexible in managing the business.

b. High levels of competition, changes in technology, and changes in customer preferences that disrupt the debtor's business processes or make it difficult for the debtor's business to grow in accordance with his business targets.

c. Geographical risk factors related to natural disasters affecting the debtor's business.

With regard to internal conditions, the failure of the debtor to fulfill his obligations to the Bank which causes credit to become problematic can be seen from two sides (from the debtor's side as well as from the Bank's side), namely as follows: ${ }^{14}$

a. From the debtor's side

1) The debtor's cooperative attitude decreases and there is a bad intention from the debtor or company management.

12 Chusna, Amalia., \& Hafidz, Jawade. (2019). The Role of the Notary in the Credit Agreement with Mortgage Guarantee (Case Study in the Bank Tabungan Negara (Persero) Tbk). JURNAL AKTA: Vol. 6, No. 4, 719-726. Retrieved from http://jurnal.unissula.ac.id/index.php/akta/article/view/7668

${ }^{13}$ Interview with Mrs. Made Linggarasih, SH (PPAT notary for the working area of Grobogan Regency (a partner of Bank Jateng, Purwodadi Branch) On March 9, 2020

${ }^{14}$ Interview with Indra Susanti, SH, Head of Section AMU, Restructuring and Settlement of Bank Jateng Loans, Wonogiri Branch. On March 10, 2020 
2) Credit received is not used for the intended purpose as agreed with the Bank.

3) Incorrect business strategy.

4) Conflicts in management, organization and personnel (for debtors who are business entities) that affect the company's business activities.

b. From the bank side

1) Inadequate credit analysis from the Bank, resulting in inaccuracies in risk assessment and mitigation, as well as over-financing (loans given are greater than the needs of the debtor)

2) Monitoring of existing credit facilities given to debtors inadequate (weak)

3) There were fraud committed by Bank employees related to lending to debtors.

4) Mastery of weak collateral both from the object or the physical building as well as its binding.

Initial efforts in managing non-performing loans, in order to obtain maximum results, require intensive collection of non-performing debtors by banks, which can also be categorized as coaching efforts, before entering into rescue steps.

Actions that can be taken by the Bank in rescuing non-performing loans include rescheduling, reconditioning, restructuring, management assistance, debt to equity swaps, and debt settlement agreements.

Credit salvage measures as described above, are sometimes not sufficient to help customers recover in carrying out their business activities or prevent the possibility of further losses for the Bank related to credit facilities provided to debtors. Under these conditions the Bank is forced to take a decision to end its relationship with the debtor through credit settlement (second way out), namely by conducting an auction for the execution of the Mortgage. ${ }^{15}$

\section{Closing}

The position of a Notary is not easy to carry out because it is full of legal risks, in relation to Banking, Notary must be able to ensure that the deed and all legal products made by him are not problematic and can actually be used as the basis for carrying out the auction for the execution of the Mortgage in a safe manner. The auction step for the execution of the Mortgage is a last resort that must be taken by the Bank to recover losses on loans that are not paid by the debtor. The process does not always run smoothly without obstacles, often the debtor takes a fight through court lawsuits so that it requires extraordinary and tiring effort, both for the debtor and the Bank. Before stepping into the second way out, Banks must offer a first way out to debtors who are still committed and capable by means of mediation and kinship in order to achieve credit settlement based on the principle of a more humane win-win solution.

\footnotetext{
${ }^{15}$ Interview with Bayu Priyo Sulistyo, SE Pincapem Bank Jateng Capem Nusukan Surakarta. On March 10, 2020
} 


\section{References}

Journals:

[1] Chusna, Amalia., \& Hafidz, Jawade. (2019). The Role of the Notary in the Credit Agreement with Mortgage Guarantee (Case Study in the Bank Tabungan Negara (Persero) Tbk). JURNAL AKTA: Vol. 6, No. 4, 719-726. Retrieved from http://jurnal.unissula.ac.id/index.php/akta/article/view/7668

[2] Firdaus, Rahmat. (2011). Manajemen Perkreditan Bank Umum, Fifth Printing. Bandung: Alfabeta. p. 46

[3] G. H. S. Lumban Tobing. (1999). Peraturan Jabatan Notaris, Gelora Aksara Pratama. Jakarta: p. 55-59

[4] Rachmayani and Suwandono. (2017). Covernote Notaris dalam Perjanjian Kredit dalam Perspektif Hukum Jaminan, Jurnal Hukum Kenotariatan dan ke-PPAT-an, ISSN: 2614-3542 EISSN: 2614-3550 Volume 1, Number 1, December 2017

[5] Setyaningsih and Mashdurohatun. (2018). Peranan Notaris Dalam Pembuatan Akta Pemberian Hak Tanggungan (APHT) Terhadap Perjanjian Kredit Antara Kreditur Dan Debitur Dengan Jaminan Hak Tanggungan Di Purwokerto. Vol 5 No 1 March 2018: 187 - 196

Books:

[1] Adjie, Habib. (2018). Hak Tanggungan Sebagai Lembaga Jaminan atas Tanah. Bandung: Mandar Maju. p. 10

[2] Adrian Sutedi. (2006). Implikasi Hak Tanggungan Terhadap Pemberian Kredit Oleh Bank dan Penyelesaian Kredit Bermasalah. Jakarta: BP Cipta Jaya. p. 1

[3] Asyhadie, Zaeni and Rahma Kusumawati. (2018). Hukum Jaminan di Indonesia. Depok: Raja Grafindo. p. 223

[4] Usanti, Prasastinah and Bakarbessy. (2014). Buku Referensi Hukum Perbankan: Hukum Jaminan, Surabaya: Revka Petra Media. p. 34-35

[5] Usman, Rachmadi. (2011). Aspek-Aspek Hukum Perbankan di Indonesia. Jakarta: Gramedia Pustaka Utama. p. 76

Interviews:

[1] Interview with Bayu Priyo Sulistyo, SE Pincapem Bank Jateng Capem Nusukan Surakarta. On March 10, 2020

[2] Interview with Indra Susanti, SH, Head of Section AMU, Restructuring and Settlement of Bank Jateng Loans, Wonogiri Branch. On March 10, 2020

[3] Interview with Mrs. Made Linggarasih, SH (PPAT notary for the working area of Grobogan Regency (a partner of Bank Jateng, Purwodadi Branch) On March 9, 2020

[4] Interview with Mrs. Made Linggarasih, SH (PPAT notary for the working area of Grobogan Regency (a partner of Bank Jateng, Purwodadi Branch) On March 9, 2020 